\title{
Co-digestion of modified tapioca starch sludge and shrimp pond sediment as a method to improve system stability and biogas production
}

\author{
Piyavadee Srivichai $^{\mathrm{a}}$, Orathai Chavalparit ${ }^{\mathrm{b}, \mathrm{c}, *}$ \\ ${ }^{a}$ Interdisciplinary Program in Environmental Science, Graduate School, Chulalongkorn University, \\ Bangkok 10330 Thailand \\ b Department of Environmental Engineering, Faculty of Engineering, Chulalongkorn University, \\ Bangkok 10330 Thailand \\ c Research Program: Sustainable Management of Industrial and Agricultural \\ Wastes for Transitioning to a Circular Economy, \\ Center of Excellence on Hazardous Substance Management (HSM), Bangkok 10330 Thailand
}

*Corresponding author, e-mail: orathai.c@chula.ac.th

Received 25 Jul 2019

Accepted 15 Feb 2020

\begin{abstract}
The objective of this research was to study the anaerobic co-digestion (ACD) process by using two combination types of modified tapioca starch sludge (SS) and shrimp pond sediment (SPS). The response surface method (RSM) was utilized based on the central composite design (CCD) for analysis. Optimum ACD ratios between SS:SPS ratios of 1:0 (pure SS) and 1:1 obtained from the biochemical methane potential (BMP) test were further utilized in a pilot continuous stirred tank reactor (CSTR) test. The CSTR results showed that the highest biogas yield could be achieved at $422 \mathrm{l} / \mathrm{kg}$ total volatile solids added $\left(\mathrm{TVS}_{\text {added }}\right)$ with a methane $\left(\mathrm{CH}_{4}\right)$ content of $46.66 \%$ using a SS:SPS ratio of 1:1. Compared with the digestion of SS alone, the biogas yield was lower at $2931 / \mathrm{kg} \mathrm{TVS}_{\text {added }}$. The completed digestion time of ACD of SS with SPS was 5 days, and a TVS removal of $51.31 \%$ was obtained. SPS could help adjust the appropriate ratio of volatile fatty acid to alkalinity (VFA/ALK) along with increasing the system stability. It can be concluded that the ACD system of SS and SPS is capable of converting waste into renewable energy as well as reducing the environmental effects from ineffective disposal management.
\end{abstract}

KEYWORDS: tapioca starch sludge, shrimp pond sediment, anaerobic co-digestion, biogas

\section{INTRODUCTION}

Tapioca starch, with a production capacity of over 5 million tons per year, plays an important role in the socioeconomics of Thailand. Thai tapioca starch is well known due to its high quality as well as economic price. In 2017, 3.04 million tons of both native and modified starch were exported with a total income of 1273 million dollars. The modified starch is produced from native tapioca starch which has been treated physically, chemically, or enzymatically to improve its properties such as gelatinization, swelling, solubility, viscosity, etc. It is widely used in various types of industry, including pharmaceuticals, paper, textiles, food and beverages. According to the production process, a large volume of starch sludge (SS) waste has been generated, especially in Rayong, which is the second highest tapioca starch producing province in Thai- land, having a total of 8 tapioca factories. Generally, $34.31 \mathrm{~kg}$ of SS were generated for each ton of modified tapioca starch produced. The SS is then further flushed in wastewater, which results in water pollution. Despite the fact that most SS is normally utilized as an ingredient in animal food production, there is an alternative method to help mitigate this issue. Anaerobic digestion (AD) is an interesting economical option for SS management because it contains a high percentage of carbon, and a carbon to nitrogen $(\mathrm{C} / \mathrm{N})$ ratio of 242 can be used as an effective carbon substrate. However, anaerobic singledigestion for SS alone may affect performance and stability during biogas production due to its low $\mathrm{pH}$. As a result, the concept of anaerobic co-digestion (ACD) is introduced to tackle this factor. According to the previous research, most of the studies that focused on ACD did not use SS as the co-substrate because of its properties mentioned earlier. The co- 
substrate examples utilized in the previous research were tapioca pulp with pig manure [1], tapioca peel with poultry piggery [2] and tapioca wastewater with biodiesel processing waste [3].

To improve the stability and performance for the ACD that utilizes SS as the substrate, shrimp pond sediment (SPS) could be used as the co-substrate for the system to function effectively. According to the previous studies, shrimp farming is among the main aquaculture activities in Rayong province, for which the farming area covers approximately 1338 hectares. Approximately 6.69 million tons of SPS are annually produced from the shrimp farming cultivation process as bulky local waste. After harvesting, most small shrimp farms directly drain their SPS to the canal, which causes water pollution and various adverse effects on the aquatic ecosystem due to its high salinity [4] and high nitrogen (N) content, which is approximately $3.20-5.98 \mathrm{gN} / \mathrm{kg}$ [5]. In general, the SPS waste is not treated properly before disposal. According to the study by Srisertpol et al [6], the utilization of SPS as an anaerobic single-substrate digestion could obtain high total volatile solids (TVS) and chemical oxygen demand (COD) removal efficiencies up to $95 \%$. However, the low biogas yield with only $25 \mathrm{l} / \mathrm{kg}$ COD due to the absence of a carbon source with a C/N ratio of 7.04 was a large downside for utilizing the SPS alone. In addition, one of the useful properties of the SPS is its slightly alkalinity, which means the SPS can be used as a potential co-substrate with SS for the ACD system.

In addition, abundant researches have also shown that ACD could improve the process stability and performance [7-10], in which SPS could be the key factor to increase the process stability and performance in ACD. Thus, the objective of this research was to enhance the biogas production from SS by using SPS as the co-substrate in the ACD system. The biochemical methane potential (BMP) method was used to determine the biogas production capacity of each mixing ratio with the help of the response surface plot for data analysis. The experiment design was based on the central composite design (CCD). The obtained optimum ratio was further used for a pilot experiment at the single stage anaerobic digestion scale. The results obtained from this research can be used to design a practical system afterwards.

\section{MATERIALS AND METHODS}

\section{Feed substrate}

SS was collected from the modified tapioca starch plant in Rayong Province, which is in the eastern part of Thailand. The starch is mostly used in the food and paper industries. The SS was sampled from the drainage ditch receiving wastewater from the reactor tank cleaning process after the sediment was deposited for $24 \mathrm{~h}$. SPS was obtained from the bottom sediment of the earthen pond located close to the tapioca starch plant. Pacific white shrimp (Litopenaeus vannamei) cultivated on that farm were fed only pallet food for 6 months. The samples were kept in plastic bags and stored in a refrigerator at $4^{\circ} \mathrm{C}$ before the experiment. Both substrates were analyzed for $\mathrm{pH}$, total solids (TS), TVS, total organic carbon (TOC), total nitrogen (TN), C/N ratio, and chloride $\left(\mathrm{Cl}^{-}\right)$.

\section{Inoculum}

Bio-sludge from the up-flow anaerobic sludge blanket (UASB) of beverage manufacturing was used as an inoculum for this experiment. The concentration for the TVS of the inoculum was prepared at 2.5\% by wet weight basis before the experiment.

\section{Experimental design}

The experimental design of the ACD was divided into 2 phases, which were BMP and continuous stirred tank reactor (CSTR) experiments.

\section{Biochemical methane potential experiment}

The BMP experiment was used to evaluate the biogas yield of the ACD system. The experiments were conducted in $125 \mathrm{ml}$ serum bottles with working volumes of $80 \mathrm{ml}$. The ratio of the inoculum to given substrate was mixed at 40:60 by volume, and the $\mathrm{pH}$ was initially adjusted using a digital $\mathrm{pH}$ meter (Mettler Toledo, Seven Easy, Metler Toledo Group, Switzerland) in the range of 6.8-7.2. The prepared sample bottles were flushed with nitrogen gas before being capped with airtight rubber stoppers. Then, the samples were incubated on a rotary shaker at a speed of $140 \mathrm{rpm}$ at a room temperature of $25-30^{\circ} \mathrm{C}$ for 45 days. The generated biogas was monitored every day using a syringe. The needle was inserted through the airtight rubber stoppers, and the syringe was filled with the biogas automatically. The volume of biogas was measured by reading the syringe scale. The methane $\left(\mathrm{CH}_{4}\right)$ content in biogas was analyzed by collecting biogas in a tedlar gas sampling bag (Restek 22049, Restesk 
Table 1 The characteristics and CCD codes for each run.

\begin{tabular}{|c|c|c|c|c|c|c|c|}
\hline \multirow{2}{*}{ Run } & \multicolumn{2}{|c|}{ CCD code } & \multicolumn{3}{|c|}{ TVS (\% wet weight) } & \multicolumn{2}{|c|}{$\mathrm{pH}$} \\
\hline & SS & SPS & Inoculum & SS & $\overline{\text { SPS }}$ & Initial & $\overline{\text { Final }}$ \\
\hline 1 & -1.414 & 0 & & $0^{\mathrm{a}}$ & 1 & 6.96 & 7.45 \\
\hline 2 & 0 & 0 & & 1 & 1 & 7.05 & 6.93 \\
\hline 3 & 1 & 1 & & 2 & 2 & 6.98 & 5.28 \\
\hline 4 & 1 & -1 & & 2 & 0 & 6.94 & 4.82 \\
\hline 5 & -1 & 1 & & 0 & 2 & 7.10 & 7.46 \\
\hline 6 & 0 & 0 & & 1 & 1 & 7.07 & 6.97 \\
\hline 7 & 0 & 1.414 & 2.5 & 1 & 2.414 & 6.97 & 6.99 \\
\hline 8 & 0 & 0 & & 1 & 1 & 7.10 & 6.95 \\
\hline $9^{*}$ & -1 & -1 & & 0 & 0 & 6.94 & 7.65 \\
\hline 10 & 0 & 0 & & 1 & 1 & 6.94 & 7.03 \\
\hline 11 & 1.414 & 0 & & 2.414 & 1 & 6.96 & 5.35 \\
\hline 12 & 0 & -1.414 & & 1 & $0^{\mathrm{a}}$ & 7.04 & 6.57 \\
\hline 13 & 0 & 0 & & 1 & 1 & 6.94 & 7.09 \\
\hline
\end{tabular}

" Run $9=$ control; ${ }^{\text {a }}$ using zero concentration instead of negative concentrations.

Corp., USA) and then analyzed by gas chromatography. The experiments were performed in triplicate. The control set using only inoculum and distilled water was also employed under similar conditions as the samples. The volatile fatty acid (VFA), alkalinity (ALK), $\mathrm{pH}$, and TVS were measured only on the starting and final days. The SS and SPS co-digestion experiments were varied at different mixing ratios by Design Expert Software version 10 based on CCD with an alpha value of 1.414. The TVS of each substrate was set in the range of $0-2 \%$ by wet weight basis. The BMP method was adopted and modified from Owen et al [11] for use in this research. A total of 13 runs of the variables were used in this experimental design. The characteristics and CCD codes for each run are shown in Table 1.

\section{Continuous stirred tank reactor experiment}

A single-stage anaerobic digestion system, CSTR, with a working volume of 51 was used in this experiment. The optimum ratios of SS to SPS obtained from the previous experiment were utilized. The ratio of inoculum to feeding substrate was $40: 60$ by volume, and the percentage of the initial TVS of the substrate was fixed at $1 \%$ TVS with batch feeding. The reactor was mixed at a speed of $70 \mathrm{rpm}$. The VFA, ALK, $\mathrm{pH}$, and temperature were monitored daily by a digital $\mathrm{pH}$ meter and thermometer. After $\mathrm{pH}$ monitoring, phosphoric acid $\left(\mathrm{H}_{3} \mathrm{PO}_{4}\right)$ and sodium bicarbonate $\left(\mathrm{NaHCO}_{3}\right)$ were used to control the entire $\mathrm{pH}$ of the mixture between 6.8 and 7.2. The biogas volume was measured by using a gas counter based on a water-gas displacement system connected to a sensor counting the number of gas displacement turnovers. The $\mathrm{CH}_{4}$ content in biogas was analyzed by collecting the biogas using the gas sampling bag. The TVS were analyzed once every three days.

\section{Gas chromatography (GC) analysis of methane}

The $\mathrm{CH}_{4}$ content in biogas from both the BMP and CSTR was analyzed by GC (Model Shimadzu GC2014, Shimadzu Corp., Japan) equipped with a thermal conductivity detector (TCD) and a molecular sieve packed column (MS-5A, stainless steel, $2.1 \mathrm{~mm}$ inside diameter, $3 \mathrm{~mm}$ outside diameter, and $2 \mathrm{~m}$ length, Restesk Corp., USA). The argon was used as a carrier gas at a flow rate of $30 \mathrm{ml} / \mathrm{min}$. The temperatures of the injector, column and detector were 150,80 , and $200^{\circ} \mathrm{C}$, respectively. All analytical methods were performed by following the APHA standard [12].

\section{Calculation and statistical analysis}

The following relationship (1) was used to prepare the feedstock with specific TVS content:

$$
\mathrm{TVS}_{1} \mathrm{~W}_{1}=\mathrm{TVS}_{2} \mathrm{~W}_{2}
$$

where TVS $_{1}$ is TVS of the feed substrate (\% wet weight), $\mathrm{W}_{1}$ is weight of substrate ( $\mathrm{g}$ ), $\mathrm{TVS}_{2}$ is TVS of feedstock (\% wet weight), and $\mathrm{W}_{2}$ is weight of feedstock $(\mathrm{g})$. The biogas yield ( $1 / \mathrm{kg} \mathrm{TVS}_{\text {added }}$ ) was calculated according to the following formula:

$$
\text { Biogas yield }=\mathrm{B} / \text { TVS }_{\text {added }} \text {, }
$$

where B is cumulative biogas volume (l) and TVS $_{\text {added }}$ is weight of total volatile solids of substrate added to the reactor $(\mathrm{kg})$. The $\mathrm{CH}_{4}$ yield $(\mathrm{l} / \mathrm{kg}$ $\mathrm{TVS}_{\text {added }}$ ) was calculated according to the following formula:

$$
\mathrm{CH}_{4} \text { yield }=\frac{\text { Biogas yield } \times \mathrm{CH}_{4} \text { content }(\%)}{100} \text {. }
$$

The TVS removal (\%) was calculated according to the following formula:

$$
\text { TVS removal }(\%)=\frac{\mathrm{TVS}_{\mathrm{i}}-\mathrm{TVS}_{\mathrm{f}}}{\mathrm{TVS}_{\mathrm{i}}} \times 100,
$$

where $\mathrm{TVS}_{\mathrm{i}}$ is the initial TVS of the mixture of inoculum and substrate (\% wet weight), and $\mathrm{TVS}_{\mathrm{f}}$ is the final TVS of the digestate (\% wet weight).

The descriptive statistics (mean and standard deviation) are used to describe the biogas yield, $\mathrm{pH}$, VFA/ALK ratio, and TVS removal. In the case of the BMP test, the response surface plot of biogas yield and TVS removal was applied to evaluate the optimum co-digestion ratios. The obtained optimum co-digestion ratios were further used in the CSTR pilot experiment. 


\section{RESULTS AND DISCUSSION}

\section{Characteristics of feed substrate}

The physical and chemical characteristics of the SS and SPS are shown in Table 2. SS from the reactor cleaning process mainly comprised the remaining modified starch in the acidic liquor with a $\mathrm{pH}$ as low as 4.48. The results from the analysis showed that the SS contained a high TOC content of $28.07 \%$. From the study of Promthong et al [13], it was found that tapioca starch contains high amylopectin, accounting for approximately 83\%, which was easier to digest than amylose. Normally, the tapioca starch was the digestible starch [14] that can induce the excess VFA generation, which results in the rapid drop of $\mathrm{pH}$ [15].

The SPS used in the experiment had a low nitrogen content of $0.05 \%$ when compared with $0.12 \%$ of SS and SPS from the southern part of Thailand. $\mathrm{Na}$ nakorn et al [5] reported that SPS from Surat Thani, Thailand, contained high nitrogen content in the range of $0.32-0.59 \%$. This might have been due to the shrimp being cultivated with only pallet food and the complete cleaning of the pond in every cultivation cycle. The SPS, however, contained a very low TOC content of approximately $0.22 \%$, which resulted in a low $\mathrm{C} / \mathrm{N}$ ratio of 4.35 . Consequently, the SPS might potentially aid in balancing the optimal $\mathrm{C} / \mathrm{N}$ ratio for the $\mathrm{AD}$ system. The $\mathrm{C} / \mathrm{N}$ ratio of the SPS was close to the values reported by Srisertpol et al [6], which were approximately 7.04 and 9.93. Additionally, the SPS consisted of a high level of $\mathrm{Cl}^{-}$, which could be toxic to the methanogens. A large amount of $\mathrm{Cl}^{-}$contains in seawater, which was used to cultivate the marine shrimp. Normally, it is being transferred from seawater into the SPS.

As a result, the utilization of SPS as feedstock for the co-digestion with the help of SS could dilute the SPS toxicity as well.

\section{The BMP experiment}

\section{Biogas yield from single SS digestion}

As shown in Fig. 1, the maximum biogas yield of $320 \mathrm{l} / \mathrm{kg}$ TVS $_{\text {added }}$ was achieved at 1\% TVS of SS. An increase in the TVS concentration resulted in a decrease in the biogas yield. The results proved that although the SS as a single substrate had high potential for biogas production, low stability, and low performance were the downsides for utilizing only the SS as a single substrate. Typically, SS is easy to digest and more rapidly fermented to VFA. At $2 \%$

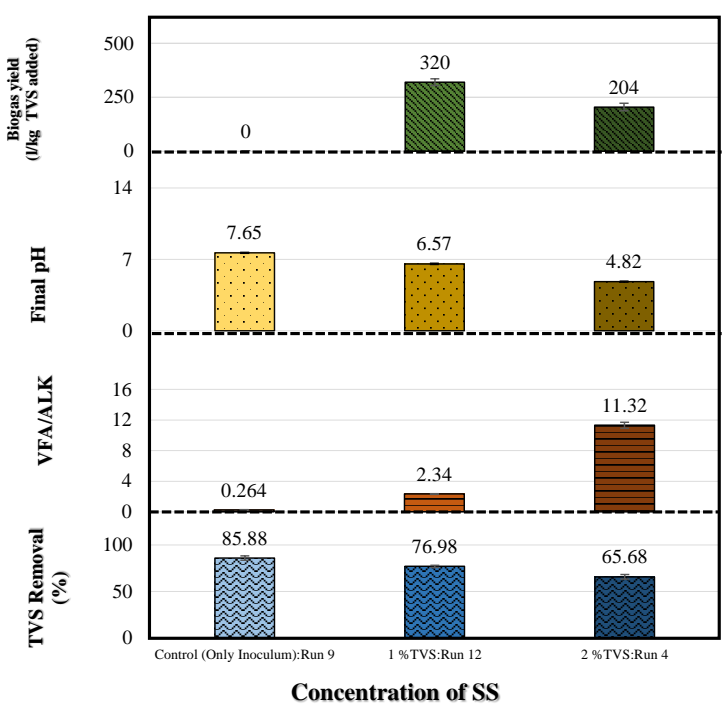

Fig. 1 The system stability and performance of single SS digestion.

TVS of SS, the SS concentrations increased. Thus, this has resulted in a faster VFA generating rate than the conversion rate of VFA to methane. The VFA was accumulated until it exceeded the optimal VFA/ALK levels between 0.1 and 0.3 [16]. The accumulation of the VFA caused the $\mathrm{pH}$ drop, which limits biogas production and microbial growth [17]. Moreover, the analysis of the $\mathrm{CH}_{4}$ content also showed low percentages, which were $42.89 \%$ and $37.08 \%$ of $\mathrm{CH}_{4}$ for 1\% TVS of SS (organic concentration: $6 \mathrm{~kg}$ TVS $/ \mathrm{m}^{3}$ ) and $2 \%$ TVS (organic concentration: $12 \mathrm{~kg}$ $\mathrm{TVS} / \mathrm{m}^{3}$ ), respectively. According to the study of Zealand et al [18], in which the AD of rice straw was carried out in $500 \mathrm{ml}$ flasks with a working volume of 4001 at mesophilic temperature $\left(37^{\circ} \mathrm{C}\right)$ by the BMP method, the organic concentrations were increased from 1 to $2 \mathrm{~kg} \mathrm{TVS} / \mathrm{m}^{3}$. They found that $\mathrm{CH}_{4}$ yield was significantly reduced as the organic concentrations were increased from 3 to $6 \mathrm{~kg}$ TVS $/ \mathrm{m}^{3}$. Thus, when utilizing SS as a single substrate for $\mathrm{AD}$, the effects of the organic concentration on the biogas yield, $\mathrm{CH}_{4}$ content, system stability, and TVS removal performance should also be considered.

\section{Biogas yield from single SPS digestion}

The results from the BMP test of biogas production using SPS as a single substrate emphasized only a small amount of biogas yield of $31 / \mathrm{kg}$ TVS $_{\text {added }}$ at $2 \%$ TVS. Moreover, the SPS had low TVS removals of $62.50 \%$ and $49.22 \%$ at $1 \%$ TVS and $2 \%$ TVS, 
Table 2 The characteristics of the substrates, inoculum and feedstock.

\begin{tabular}{|c|c|c|c|c|c|c|}
\hline \multirow{2}{*}{ Parameter } & \multirow{2}{*}{ SS } & \multirow{2}{*}{ SPS } & \multirow{2}{*}{ Inoculum } & \multicolumn{3}{|c|}{ Mixture of SS:SPS } \\
\hline & & & & $1: 0$ & $1: 1$ & $0: 1$ \\
\hline $\mathrm{pH}$ & $4.48 \pm 0.01$ & $7.82 \pm 0.05$ & - & - & - & - \\
\hline TS (\%) & $61.00 \pm 0.45$ & $35.64 \pm 2.24$ & $6.95 \pm 0.14$ & 2.20 & 5.83 & 4.66 \\
\hline TVS (\%) & $31.26 \pm 0.00$ & $5.82 \pm 0.25$ & $6.74 \pm 0.03$ & 1.60 & 2.19 & 1.60 \\
\hline $\mathrm{C} / \mathrm{N}$ ratio & 242 & 4.35 & 8.51 & 35.21 & 23.57 & 6.82 \\
\hline TOC (\%) & 28.07 & 0.22 & - & - & - & - \\
\hline $\mathrm{TN}(\%)$ & 0.12 & 0.05 & - & - & - & - \\
\hline $\mathrm{Cl}^{-}(\%)$ & 0.31 & 1.33 & - & 0.006 & 0.141 & 0.135 \\
\hline
\end{tabular}

${ }^{\text {a }}$ Data via calculation.

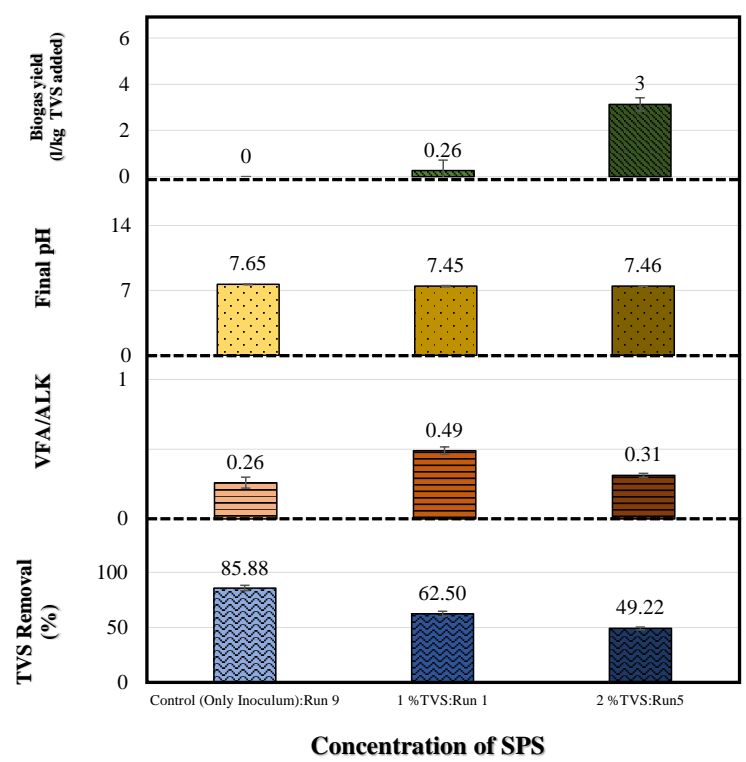

Fig. 2 The system stability and performance of single SPS digestion.

respectively (Fig. 2). This may be caused by the low content of TOC and $\mathrm{C} / \mathrm{N}$ ratio (Table 2) compared with the optimum $\mathrm{C} / \mathrm{N}$ ratio [19]. Similarly, the study of Srisertpol et al [6] also found that SPS with a $\mathrm{C} / \mathrm{N}$ ratio of 7.04 could produce biogas at only $25 \mathrm{l} / \mathrm{kg}$ COD and contained only $44.34 \% \mathrm{CH}_{4}$ content. The increase of initial feeding TVS of SPS from 1 to $2 \%$ TVS resulted in an increase in biogas yield but a decrease in TVS removal. It was indicated that the conversion rate of TVS to biogas in the $2 \%$ TVS of SPS (biogas yield of $6.10 \mathrm{l} / \mathrm{kg}$ $\mathrm{TVS}_{\text {removed }}$ ) was significantly higher than in the $1 \%$ TVS of SPS (biogas yield of $0.421 / \mathrm{kg}$ TVS $_{\text {removed }}$ ). The final $\mathrm{pH}$ above 7 with a high ALK from SPS could provide a buffer capacity for stability improvement in ACD with SS. Increasing the SPS content could enhance the optimum VFA/ALK ratio for the AD system.

\section{The co-digestion of SS and SPS}

It was observed that the SS played a major role as the feed substrate for biogas production. The increasing of SS concentrations resulted in an increasing biogas yield, as shown by the response surface plot in Fig. 3. The maximum biogas and $\mathrm{CH}_{4}$ content using SS as a single substrate at $1 \%$ TVS were $320 \mathrm{l} / \mathrm{kg}$ TVS $_{\text {added }}$ and $42.89 \%$, respectively. For the co-digestion of SS and SPS at the ratio of 1:1, the biogas yield was reduced to $295 \mathrm{l} / \mathrm{kg}$ TVS $_{\text {added }}$. However, the co-digestion of SS and SPS had a higher $\mathrm{CH}_{4}$ content of $53.47 \%$ when compared to using SS as a single feed substrate. The results also showed that the co-digestion of SS with SPS (1:1) could improve the stability and performance of ACD with an appropriate $\mathrm{pH}$ and VFA/ALK ratio of 6.99 and 0.38 , respectively (Fig. 4). The advantages for the stability and performance optimization from ACD can also be found in other studies, examples being the ACD system of fruit and vegetable waste with food waste [7], dewatered sludge with food waste [8] and food waste with activated sludge [9].

The results of the BMP test of the mixing between SS and SPS at a ratio of 1:1 showed that the obtained $\mathrm{CH}_{4}$ yield was approximately $158 \mathrm{l} / \mathrm{kg} \mathrm{TVS}$ added, which was lower than that of the other substrates such as the mixture of tapioca pulp and pig manure at a ratio of 60:40 from CSTR test, which had a $\mathrm{CH}_{4}$ yield of approximately $370 \mathrm{l} / \mathrm{kg}$ TVS $_{\text {added }}$ [20]. Several studies of the codigested substrates from BMP experiment had an average $\mathrm{CH}_{4}$ yield in the range of $168-4671 / \mathrm{kg}$ $\mathrm{TVS}_{\text {added }}$ [21]. This BMP experiment achieved the yield close to the yield in BMP test of the codigestion of manure separated liquid:whey at ratio of 3:1 (168 l/kg TVS added $)$. But CSTR experiment 


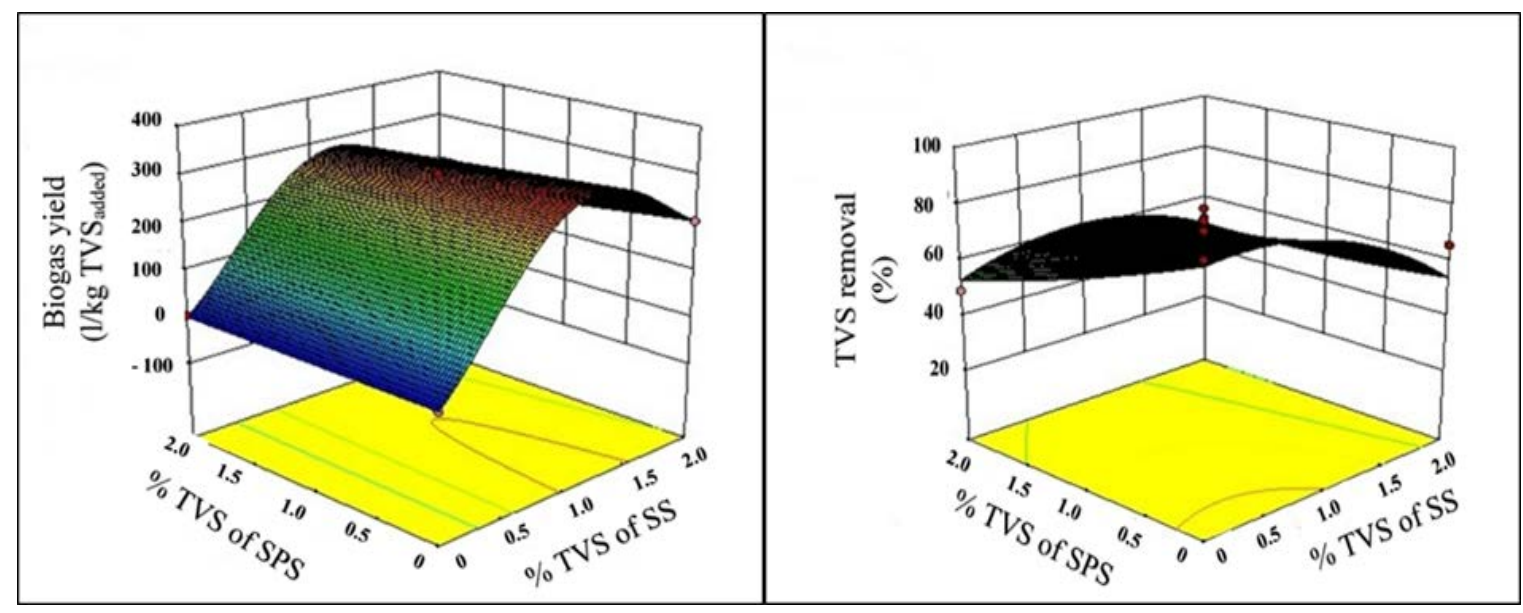

Fig. 3 The response surface plots of biogas yield and TVS removal.

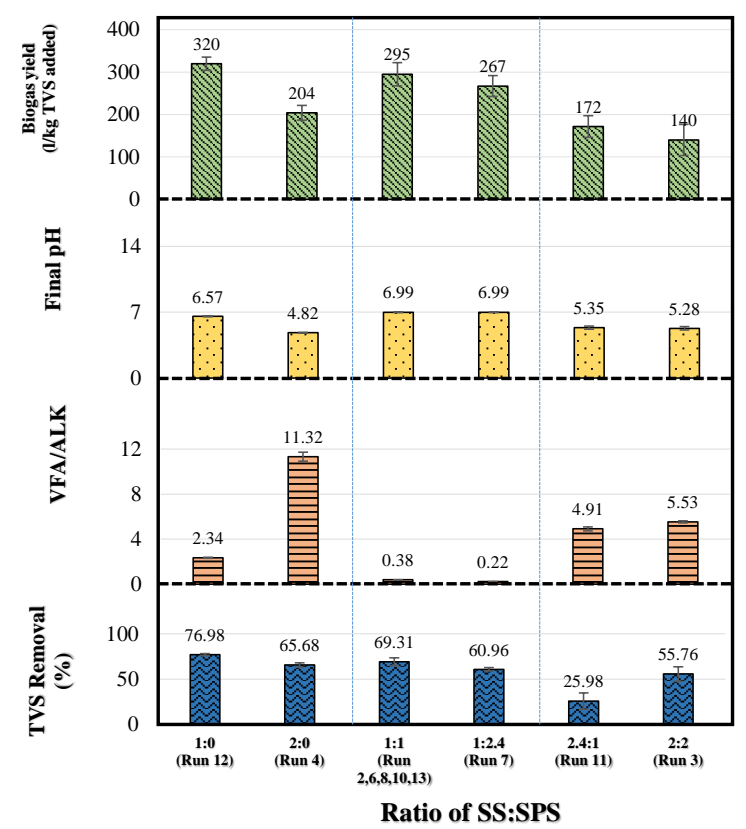

Fig. 4 The system stability and performance of codigestion.

has been obviously shown to significantly increase the methane yield higher than this BMP experiment because CSTR experiment was conducted with complete mixing propeller. Therefore, CSTR should be used for further study. The SS concentrations also mainly influenced the TVS removal when comparing the same biogas yield, as shown in Fig. 3. The co-digestion of SS:SPS at ratios of $1: 1$ and 1:2.4 showed the appropriate operating performance with neutral final $\mathrm{pH}$ values of 6.99 and 6.99 and low
VFA/ALK ratios of 0.38 and 0.22 , respectively.

The mixed liquor characteristics are shown in Table 2. It was observed that the $\mathrm{C} / \mathrm{N}$ ratios for the co-digestion ratios of 1:0 (pure SS) and 1:1 were 35.21 and 23.57, respectively, which were close to the recommended $\mathrm{C} / \mathrm{N}$ ratios, which ranged from 20-30 [19]. The CSTR experiment was undertaken with further analysis on the operational performance of ACD for the mixture of SS and SPS at the ratio of 1:1 compared with using SS and SPS as the pure feedstock later.

\section{The CSTR experiment}

Because the BMP experiment was conducted in a closed bottle without proper control of $\mathrm{pH}$, the biogas, and $\mathrm{CH}_{4}$ content were impacted [22]. The co-digestion ratios of SS:SPS of 1:0, 0:1 and 1:1 with the percentage of initial TVS of the feedstock of $1 \%$ were used for this experiment. The results showed that the highest biogas yield was achieved at $4221 / \mathrm{kg}$ TVS $_{\text {added }}$ at the SS:SPS ratio of $1: 1$ with a shorter retention time of 5 days as shown in Fig. 5a. The significantly decreased $\mathrm{pH}$ was observed because SS consists of a biodegradable starch [15]. The $\mathrm{pH}$ decreases due to the accumulation of volatile fatty acids from starch digestion (Fig. 5b). The result was confirmed by Anunputtikul and Rodtong [23], who reported on the AD of tapioca tubers in 51 single phase digesters. The digesters were operated on a batch feeding with the slurry of dry tapioca tubers using 0.5 to $4 \%$ weight by volume and incubated at an ambient temperature $\left(29-31^{\circ} \mathrm{C}\right)$ for 30 days. The $\mathrm{pH}$ of the digesters was significant decreased to less than 7 within 3 days. 

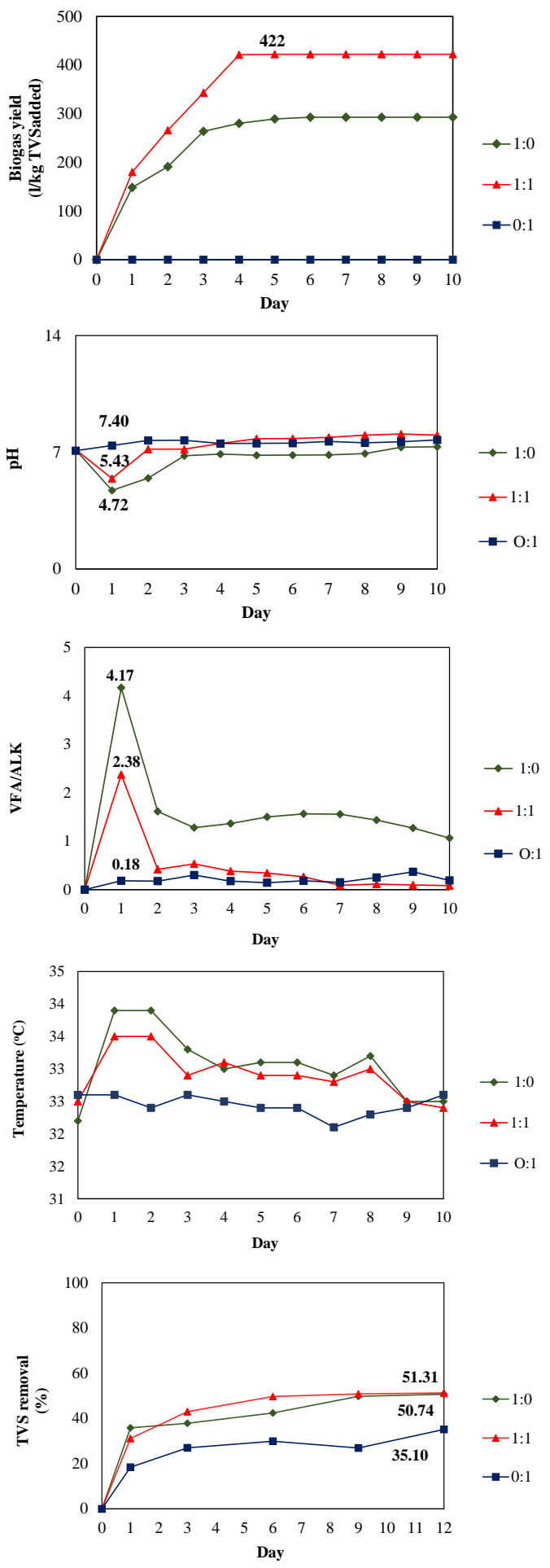

Fig. 5 Operating performance of CSTR reactor: (a) biogas yield, (b) pH, (c) VFA/ALK, (d) temperature, and (e) TVS removal.
Table 3 Comparison between the BMP and CSTR experiment on the ACD of SS:SPS (1:1).

\begin{tabular}{|c|c|c|}
\hline Parameter & BMP & CSTR \\
\hline Biogas yield $\left(1 / \mathrm{kg}\right.$ TVS $\left._{\text {added }}\right)$ & 295 & 422 \\
\hline $\mathrm{CH}_{4}$ content $(\%)$ & 53.47 & 46.66 \\
\hline Digestion time (day) & 45 & 5 \\
\hline TVS Removal (\%) & 69.31 & 51.31 \\
\hline Final pH & 6.99 & 8.03 \\
\hline VFA/ALK ratio & high $=0.38$ & low $=0.08$ \\
\hline
\end{tabular}

The results also showed that the co-digestion of SS:SPS at a 1:1 ratio was the most appropriate condition for system stabilization with a VFA/ALK ratio of less than 0.4 (Fig. 5c) and a $\mathrm{pH}$ range between 7.10-7.75 for the entire system operation. The SPS obtained from marine shrimp farming containing various buffer systems (chemicals) such as bicarbonate and borate buffer [24] could aid in stabilizing the $\mathrm{pH}$ fluctuations. Moreover, the $\mathrm{CH}_{4}$ yield significantly improved to $197 \mathrm{l} / \mathrm{kg}$ TVS $_{\text {added }}\left(\mathrm{CH}_{4}\right.$ content of $46.66 \%$ ) for the co-digestion SS:SPS ratio of $1: 1$ compared with using the pure SS, which obtained $119 \mathrm{l} / \mathrm{kg} \mathrm{TVS}$ added $\left(\mathrm{CH}_{4}\right.$ content of $\left.40.40 \%\right)$. The co-digestion SS:SPS ratio of $1: 1$ also obtained the maximum TVS removal of $51.31 \%$ (Fig. 5e). It showed that the TVS removal efficiencies for both co-digestion ratios of 1:0 and 1:1 are not different, but there is a significant difference in biogas yield, indicating that $1 \mathrm{~kg}$ of TVS removed at the codigestion ratio of 1:1 (822 1/kg TVS $\left._{\text {removed }}\right)$ can be converted into a significantly higher biogas yield than that for the (pure SS) co-digestion ratio of $1: 0\left(5771 / \mathrm{kg}\right.$ TVS $\left._{\text {removed }}\right)$. From the results, it can be concluded that the co-digestion SS:SPS ratio of 1:1 may improve biogas yield and methane content, including process stability and performance.

\section{Comparison of co-digestion using the BMP and CSTR experiment}

According to the results, the co-digestion in CSTR can improve the biogas yield up to 1.43 times with a shorter digestion time compared with the BMP experiment, which is shown in Table 3. It is known that SS can be rapidly digested within 3 days. Theoretically, the high digestion rate can lead to high VFA generation, which leads to significant $\mathrm{pH}$ drops, disrupting the methanogens later. Consequently, the ability to adjust the improper $\mathrm{pH}$ automatically in the CSTR can improve both biogas yield and stability with the shorter retention time. According to Sumadiono et al [22], being able to adjust the $\mathrm{pH}$ 
could enhance better bacterial growth and biogas generation in 51 of anaerobic digesters operated with wastewater from the alcohol industry (vinasse) in mesophilic conditions and with batch feed. The CSTR yield represents more possibilities for the use of the co-digestion of SS:SPS to produce biogas as alternative energy. The co-digestion of SS and SPS is economical way to control $\mathrm{pH}$ in $\mathrm{AD}$ system by reducing chemicals for $\mathrm{pH}$ adjustment. Moreover, there are environmental advantages in eliminating improper SPS disposal. Finally, the BMP experiment can be used as a guideline, and the pilot experiment in the reactor with the properly controlled digestion conditions is required to approve the setup conditions for the appropriate $\mathrm{AD}$ system.

\section{CONCLUSION}

This research indicated that by using marine SPS as a co-substrate with modified tapioca SS could increase biogas yield including the stability improvement and performance in the ACD system due to the buffer capacity of SPS. The response surface plot showed that the biogas yield mainly depended on the SS concentration. The co-digestion at a SS:SPS ratio of 1:1 in the CSTR obtained the highest biogas and $\mathrm{CH}_{4}$ content with a short digestion time. In addition, the system also achieved the maximum TVS removal. To summarize, the operation of the ACD system utilizing the modified tapioca SS and SPS as the co-substrate was among the effective ways of converting the waste into a renewable energy source. However, further research is required to find the most appropriate concentration of the initial TVS feedstock and digestion conditions.

Acknowledgements: The authors would like to greatly acknowledge the Royal Golden Jubilee (RGJ) Ph.D. Programme, the Thailand Research Fund (TRF) and the Office of Higher Education Commission (OHEC) and the S\&T Postgraduate Education and Research Development Office (PERDO) for the financial support.

\section{REFERENCES}

1. Panichnumsin P, Nopharatana A, Ahring B, Chaiprasert P (2010) Production of methane by co-digestion of cassava pulp with various concentrations of pig manure. Biomass Bioenergy 34, 1117-1124.

2. Adelekan BA (2012) Cassava as a potent energy crop for the production of ethanol and methane in tropical countries. Int $J$ Therm Environ 4, 25-32.

3. Kullavanijaya P, Thongduan P (2012) Enhanced biogas production in anaerobic digestion of cassava wastewater though supplementation of biodiesel waste as co-substrate. Int $J$ Renew Energy Resour 2, 510-515.

4. Dierberg FE, Kiattisimkul W (1996) Issues, impacts, and implications of shrimp aquaculture in Thailand. Environ Manage 20, 649-666.

5. Na-nakorn A, Chevakidagarn P, Danteravanich S (2017) Environmental impact of white shrimp culture during 2012-2013 at Bandon Bay, Surat Thani Province: A case study investigating farm size. Agric Nat Resour 51, 109-116.

6. Srisertpol J, Srinakorn P, Kheawnak A, Chamniprasart K, Srikaew A (2013) Estimation of biogas production from shrimp pond sediment using the artificial intelligence. Appl Mech Mater 260, 695-700.

7. Lin J, Zuo J, Gan L, Li P, Liu F, Wang K, Chen L, Gan $\mathrm{H}$ (2011) Effects of mixture ratio on anaerobic codigestion with fruit and vegetable waste and food waste of China. J Environ Sci 23, 1403-1408.

8. Dai X, Duan N, Dong B, Dai L (2013) High-solids anaerobic co-digestion of sewage sludge and food waste in comparison with mono digestions: stability and performance. Waste Manage 33, 308-316.

9. Heo NH, Park SC, Kang H (2004) Effects of mixture ratio and hydraulic retention time on single-stage anaerobic co-digestion of food waste and waste activated sludge. J Environ Sci Health A 39, 1739-1756.

10. Zahan Z, Othman MZ, Rajendram W (2016) Anaerobic co-digestion of municipal wastewater treatment plant sludge with food waste: a case study. Biomed Res Int 2016, ID 8462928.

11. Owen WF, Stuckey DC, Healy LB, Young LY, McCarty PL (1979) Bioassay for monitoring biochemical methane potential and anaerobic toxicity. Water Res 13, 485-492.

12. Rice EW, Baird RB, Eaton AD (2017) Standard Methods for the Examination of Water and Wastewater, APHA, Washington, DC.

13. Promthong S, Kanto U, Tirawattanawanich C, Tongyai S, Isariyodom S, Markvichitr K, Engkagul A (2005) Comparison of nutrient compositions and carbohydrate fractions of corn, cassava chip and cassava pellet ingredients Animals. In: Proceeding 43th Kasetsart University Annual Conference, Thailand.

14. Pereira BLB, Leonel M (2014) Resistant starch in cassava products. Food Sci Technol 34, 298-302.

15. Cuzin N, Farinet JL, Segretain C, Labat M (1992) Methanogenic fermentation of cassava peel using a pilot plug flow digester. Bioresour Technol 41, 259-264.

16. Barampouti EM, Mai ST, Vlyssides AG (2005) Dynamic modelling of the ratio volatile fatty acids/bicarbonate alkalinity in a UASB reactor for potato processing wastewater treatment. Environ Monit Assess 110, 121-128.

17. Dobre P, Nicolae FN, Matei F (2014) Main factors affecting biogas production - an overview. Romanian Biotechnol Lett 19, 9283-9296. 
18. Zealand AM, Roskilly AP, Graham DW (2017) Effect of feeding frequency and organic loading rate on biomethane production in the anaerobic digestion of rice straw. Appl Energy 207, 156-165.

19. Dioha IJ, Ikeme CH, Nafi'u T, Soba NI, Yusuf MBS (2013) Effect of carbon to nitrogen ratio on biogas production. Int Res J Nat Sci 1, 1-10.

20. Panichnumsin P, Nopharatana A, Ahring P, Chaiprasert B (2012) Enhanced biomethanation in co-digestion of cassava pulp and pig manure using a two-phase anaerobic system. $J$ Sustainable Energy Environ 3, 73-79.

21. Labatut RA, Angenent LT, Scott NR (2011) Bio- chemical methane potential and biodegradability of complex organic substrates. Bioresour Technol 102, 2255-2264.

22. Sumardiono S, Syaichurrozi I, Budiyono, Sasongko SB (2013) The effect of COD/N ratios and pH control to biogas production from vinasse. Int $J$ Biochem Res Rev 3, 401-413.

23. Anunputtikul W, Rodtong S (2004) Laboratory scale experiments for biogas production from cassava tubers. In: Proceeding Joint International Conference on Sustainable Energy and Environment, Thailand.

24. Chester R (2000) Marine Geochemistry, Chapman and Hall Ltd., London. 